\title{
Metrics of Success for Nearshore Nourishment Projects Constructed with Dredged Sediment
}

\author{
by Brian C. McFall, Douglas R. Krafft, Hande McCaw, Brooke M. Walker
}

PURPOSE: This Regional Sediment Management Technical Note (RSM TN) provides practical metrics of success for nearshore nourishment projects constructed with dredged sediment. Clearly defined goals and performance metrics for projects will set clear expectations and will lead to longterm project support from local stakeholders and the public.

BACKGROUND: The US Army Corps of Engineers (USACE) dredged more than 222 $\mathrm{M} \mathrm{yd}^{3(*)}$ $\left(170 \mathrm{M} \mathrm{m}^{3}\right)$ of sediment from navigation channels in fiscal year 2018 (USACE 2019). This dredged sediment is a valuable asset and can often be used to nourish beaches and wetlands through placement in the nearshore. Nearshore nourishment projects are defined as any project that places sediment between the swash zone and the depth of closure (Krafft et al. 2020). The beneficial use of dredged sediment is a priority for the USACE, and placing the sediment in the nearshore aligns with both Regional Sediment Management (RSM) goals by keeping the sediment in the littoral system, and the Engineering With Nature ${ }$ initiative by allowing waves to naturally sort and transport the placed sediment.

The 21 USACE Coastal and Great Lakes Districts were interviewed from March to July 2020 to compile the current state of practice of nearshore nourishment projects constructed with dredged sediment and to identify practical metrics to define successful projects. Each district was asked to bring together a diverse group from their respective design, planning, operations, and regulatory sections to compile a comprehensive perspective on these projects during these interviews. This RSM TN is the compilation of metrics that can be used to define project success from these meetings.

INTRODUCTION: The goals of each placement project dictate the best success metrics to use. Not all metrics noted in this RSM TN will be appropriate for all projects. Nearshore nourishment projects tend to fall within the USACE civil works missions of navigation, flood risk management, or ecosystem restoration and habitat development. The Federal Standard is particularly relevant for nearshore nourishment projects using dredged sediment from navigation channels. The Federal Standard is defined in USACE regulations as the least costly dredged material disposal or placement alternative identified by USACE that is consistent with sound engineering practices and meets all federal environmental requirements, including those established under the Clean Water Act and the Marine Protection, Research, and Sanctuaries Act (MPRSA) (33 CFR 335.7, 53 FR 14902). Nearshore nourishment can be the least cost alternative, but in cases that it is not the least cost alternative, cost-sharing partners are often identified to financially contribute for the additional cost. When cost-sharing partners are involved, it is critical to carefully identify and

\footnotetext{
${ }^{*}$ For a full list of the spelled-out forms of the units of measure used in this document, please refer to US Government Publishing Office Style Manual, 31st ed. (Washington, DC: US Government Publishing Office 2016), 248-52, https://www.govinfo.gov/content/pkg/GPO-STYLEMANUAL-2016/pdf/GPO-STYLEMANUAL-2016.pdf.
} 
mutually define success metrics that target threshold values where feasible, to evaluate the project performance and maintain continued support for the project.

Successful projects can be defined and evaluated by various metrics based on project goals and location. Metrics and considerations are described in this RSM TN for each phase of the project, specifically the design, construction, post-construction monitoring, and adaptive management phases. When selecting success and performance metrics for projects, the following should be considered:

- Spatial and temporal fidelity

- Scalability

- Measurability

- Understandability.

Each of these items is considered in the discussion of metrics for each project phase.

PROJECT DESIGN CONSIDERATIONS: The design rigor of nearshore nourishment projects may vary depending on a range of circumstances (e.g., dredged volume, habitat locations, distance from navigation channel), but all nearshore nourishment projects benefit from some design considerations. The following items should be considered in the project design:

- Littoral zone

- Hydrodynamic conditions

- Expected sediment transport direction

- Sediment budget

- Sediment characteristics of dredged material and the placement area

- Metrics required for 401 Clean Water Certificate

- Is nearshore placement the least cost alternative?

- Is there a long-term strategy for adaptive management?

- Expected equipment and limitations

- Expected volume.

Littoral Zone. Placing sediment within the littoral zone is important to ensure the sediment will move and nourish the beach profile. The littoral zone is defined as the zone from the exposed beach into the water to the inner depth of closure (Komar 1998). The inner depth of closure is the maximum water depth for sediment motion initiation by median wave conditions (Hallermeier 1981). Hallermeier (1981) also defined an outer depth of closure as the seaward extent where wave shoaling is the dominant process and bed agitation remains relatively moderate. The littoral zone is where the bed experiences extreme activity caused by waves breaking and their related currents.

The depth of closure can be estimated using empirical relationships (Hallermeier 1978, 1981; Birkemeier 1985; Kraus et al. 1998; Hartman and Kennedy 2016) or identified as the location at which beach profiles converge over time (Hartman and Kennedy 2016). Brutsché et al. (2016) applied the empirical depth of closure calculations to the entire United States coastline. Hands and 
Allison (1991) used the inner and outer depth of closure relationships by Hallermeier (1981) to better understand the relationship of historical active and stable nearshore berms, and McFall et al. (2021) extended this figure to include a total of 20 historical sites as shown in Figure 1. A nearshore berm is a type of nearshore nourishment where sediment is intentionally placed in a manner to create a mound or artificial sandbar. Hands and Allison (1991) found that nearshore berms placed in the littoral zone (shallower than the inner depth of closure) were active, and nearshore berms built deeper than the outer depth of closure were stable. Nearshore berms built $50 \%$ shallower than the outer depth of closure were active, but to varying degrees.
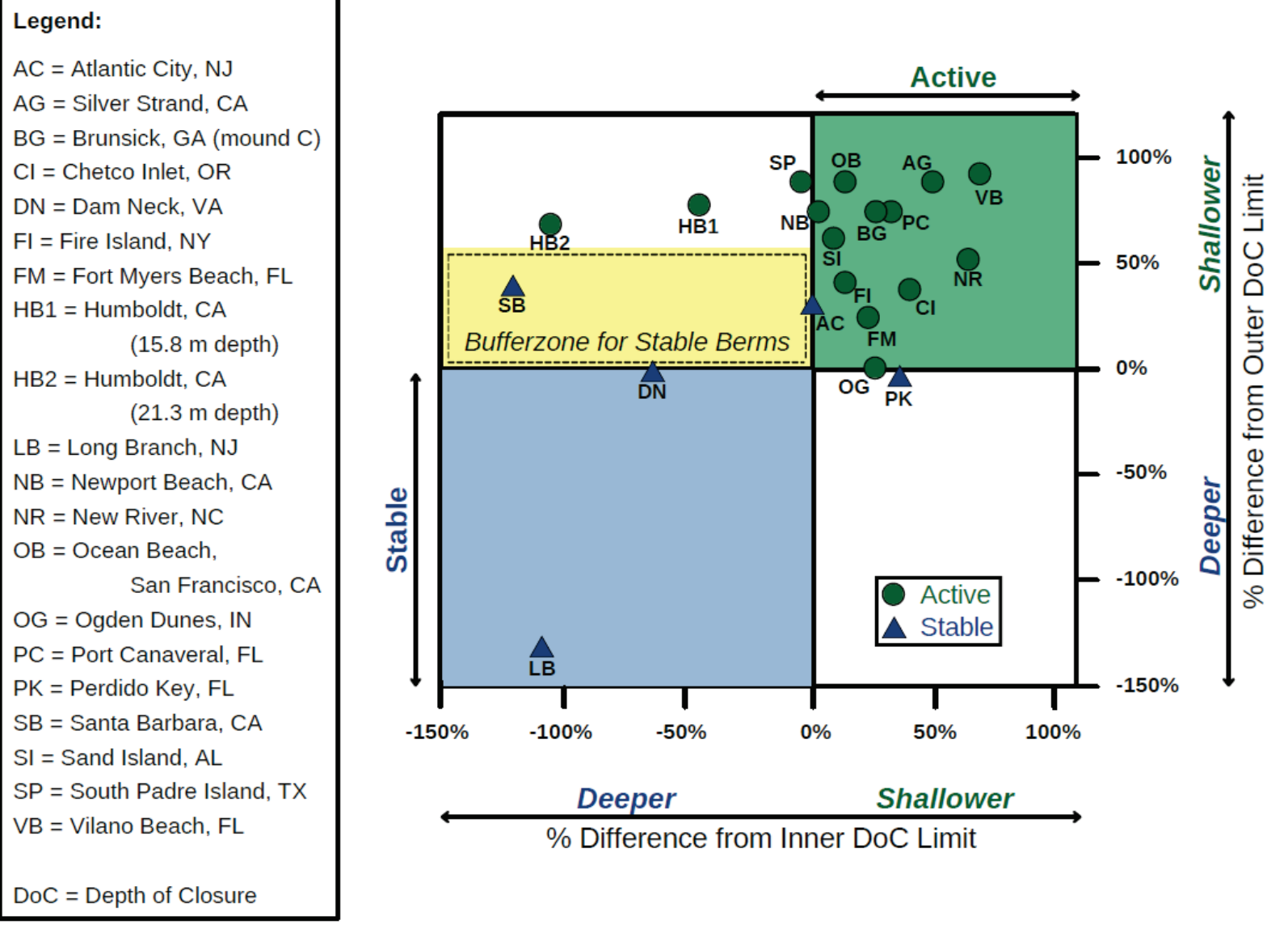

Figure 1. Placement depths for active and stable historical nearshore berms. From McFall et al. (2021), adapted from Hands and Allison (1991).

Hydrodynamic Conditions and Expected Sediment Transport Direction. The hydrodynamic conditions at a nearshore nourishment site are critical for understanding the sediment transport direction and rate of transport. Offshore wave conditions can be estimated using offshore wave buoys, such as the National Data Buoy Center (https://www.ndbc.noaa.gov/) or using offshore wave hindcasts, such as the Wave Information Study (WIS) (https://wis.usace.army.mil), which provides offshore wave conditions for the entire coastline of the United States (Hubertz 1992). Output from ADCIRC/STWAVE modeled storm events is also available at select locations within US jurisdiction for the entire Atlantic basin, Gulf of Mexico, and Great Lakes via the Coastal Hazards System (Nadal-Caraballo et al. 2020). 
The Sediment Mobility Tool (SMT) is a scoping-level web application that can quickly assess nearshore hydrodynamics and sediment transport to assist coastal engineers and planners with identifying nearshore placement sites for dredged sediment (McFall and Brutsché 2018). The web application can be found on the Navigation Portal (http://navigation.usace.army.mil). The SMT transforms offshore wave hindcasts from WIS to a proposed nearshore site and calculates the depth of closure using empirical relationships, frequency with which placed sediment will be mobilized (McFall et al. 2016), cross-shore sediment migration direction, and axis of wave-dominated sediment transport. The tool is intended to address two common questions of whether sediment placed in the nearshore will move and where it is likely to go. The Los Angeles and Jacksonville Districts noted the importance of showing the placed sediment actively moves. This proves the sediment was placed in the littoral system and is actively nourishing the beach profile.

Sediment Budget. Sediment budgets are excellent sources of information about sediment sources, sinks, transport pathways, and volumes of sediment transport for a region. The Sediment Budget Analysis System (SBAS) is a tool to assist in the creation of a sediment budget for regions with one or multiple inlets (Rosati and Kraus 1999). The SBAS program has been developed to seamlessly incorporate geomorphic features from airborne lidar (Dunkin et al. 2020). Sediment budgets are useful tools to estimate how quickly sediment moves in the nearshore and act as evidence that sediment placed in the nearshore benefits the shoreline by keeping sediment in the system.

Additional Considerations. The sediment characteristics of dredged sediment and the area of placement must be considered in nearshore nourishment projects. The requirements vary by state, but sediment restrictions are often less stringent for sediment placed in the nearshore than for sediment placed directly on the subaerial beach. As an example, navigation channel Operations and Maintenance dredged material requirements for beach nourishment projects established by the Florida Department of Environmental Protection in 62B-41.007(2)(j-k) require dredged material to have a maximum of $10 \%$ fine material for direct subaerial beach placement or up to $20 \%$ fine material for placement in the nearshore.

Additional design considerations may be required to attain the 401 Clean Water Certificate for nearshore nourishment projects, which is a state certification of water quality. Requirements for the certificate vary state by state, but projects may require turbidity monitoring or habitat monitoring. Environmental impacts should be mitigated by identifying sub-aquatic vegetation, oyster beds, coral, and other critical habitat. If placing dredged sediment in the nearshore is not the least-cost placement alternative, setting clear and realistic expectations with cost-sharing partners is critical. Finally, adaptive management plans are important to consider from the initial design. Alternate placement locations to target erosion hotspots on the beach and placement depth modifications to control the lifespan of the nearshore nourishment are useful to consider.

CONSTRUCTION METRICS: Metrics showing that dredged sediment was planned and successfully placed in the nearshore improves the understanding of the sediment transport and shoreline response to the placement. Considerations for construction metrics revolve around addressing the following questions:

- Was the sediment placed in the planned location?

- How thick was the placement?

- Were waves seen breaking over the placed sediment during construction? 
Identifying the placement locations, attaining the placement target elevation, and qualitatively understanding the initial influence of the placement on the hydrodynamics provide particularly valuable information during construction.

Placement Location. Identifying the placement location is relevant in terms of depth and longshore position. The placement depth may be restricted by the construction technique. Bottom dumping hoppers and scows require a minimum underkeel clearance to prevent damage to the vessel, and the wave-induced transport rate of the placed sediment is directly proportional to the placement depth (Bain et al. 2021). To place sediment in less than $10 \mathrm{ft}(3 \mathrm{~m})$ of water, sediment can be hydraulically pumped into the nearshore.

To quantify where sediment is placed by hoppers and scows, the location of each placement is typically recorded by the boat captain. Contractors are required to record this using the Dredging Quality Management Program, and the USACE hopper fleet can record this as well. Figure 2 shows the placement plan and placement location for the USACE split-hull special purpose dredge Murden at Vilano Beach, Florida. The plan consists of colored vessel heading lines and the actual placement locations shown as matching colored circles. The dredge was instructed to "nose in" along the placement line and then split the hopper to place the sediment as shallow as possible given the tide. The dredge was instructed to begin with a placement on the most northern line and to make subsequent placements on each line of the same color moving south, then repeat for the next color (McFall et al. 2017). These two nearshore berms were constructed in depths of 5-12 ft (1.5-3.7 m) (Brutsché et al. 2017). By recording the placement locations, a simple metric of how much sediment was placed in specific areas can be easily determined. 


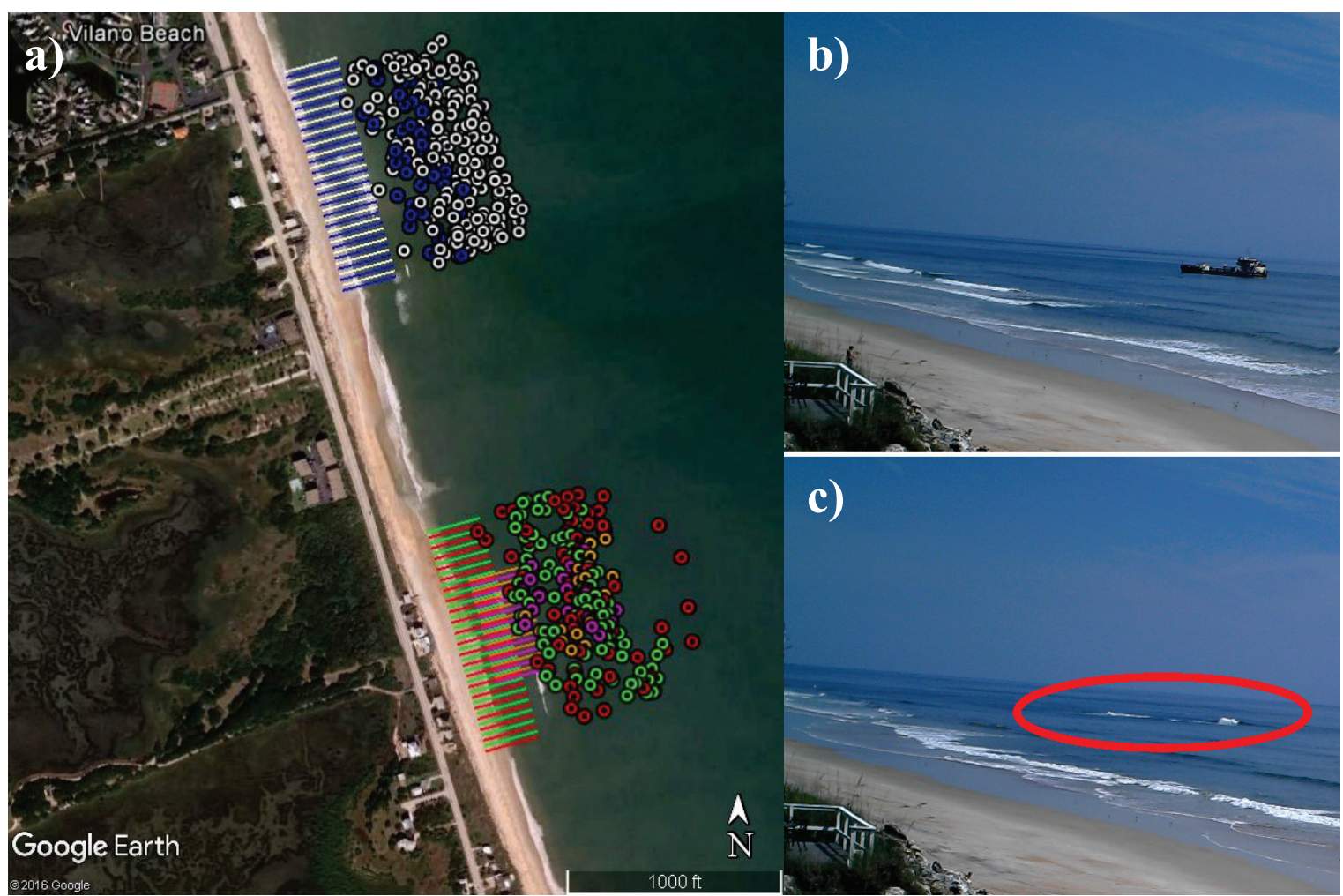

Figure 2. (a) Heading lines and placement locations (colored circles) for the two nearshore berms at Vilano Beach, Florida; (b) hopper dredge placing sediment in the nearshore; and (c) wave breaking observed over the placed sediment.

Placement Thickness. Depending on the project's goals, quantifying the placement thickness can be a critical success metric for stakeholder support. Many shoreline protection projects prefer a thick placement such as a bar-shaped nearshore berm to dissipate wave energy directly impacting the shoreline (e.g., Vilano Beach project). Surveys during construction can assist the district and the contractor to make sure placement quantities and target placement elevations are achieved.

Other projects prefer for the placement to be placed as a thin layer, such as at the mouth of the Columbia River, OR (MCR) (Norton et al. 2018), and Mobile Bay, AL (Parson et al. 2015). Hopper dredges are ideal vessels for thin layer placement. These thin layer placements are generally intended to minimize the environmental and hydrodynamic impacts of the placement. The MCR project has an annual use plan that gets approved by the state prior to placement. The current rule for placement depth is not to exceed $10 \%$ of the water column from the first time the site was used. To minimize errors that might cause unintended impacts to the dredge and placement sites, high quality bathymetric surveys are required. When contracting dredge work at the MCR, the contractor is required to survey placement sites every $48 \mathrm{hr}$. This is for internal review to do quality control on the quantity placed.

Immediate Hydrodynamic Response. Waves can often be observed breaking over newly placed sediment. This was observed at Vilano Beach, FL, New Smyrna Beach, FL (Pruett 2019), and Newport Beach, CA (Mesa 1996), among others. The waves breaking at New Smyrna Beach and Newport improved surfing conditions and garnered support from the surfing community for 
these projects. Identifying waves breaking at the placement site can be done by USACE personnel in the field or captured by remote cameras. The images of waves breaking at Vilano Beach, FL, in Figure 2 were captured with an inexpensive game camera attached to the balcony of a beach house.

At the MCR, six cameras are set up for an Argus system, and the results are posted every $20 \mathrm{~min}$ on a public website. These data are utilized by federal agencies and the public (e.g., the USACE, Coast Guard, fishermen). The imagery qualitatively shows where waves are breaking to help make decisions and show the public how the placement is impacting wave behavior. This transparency has helped garner public support for other nearshore projects.

Rapidly deployable mini-Argus camera systems can support nearshore nourishment projects if there is a tall building or structure that allows for the installation of cameras. The mini-Argus system that was deployed to monitor the hydrodynamics and shoreline response to the nearshore berm construction and post construction response at New Smyrna, FL (Bruder et al. 2019), is shown in Figure 3. The cameras were installed on the rooftop of a nearby building. The camera directly captures the wave characteristics and shoreline position, and the nearshore bathymetry can be inferred from the wave characteristics.
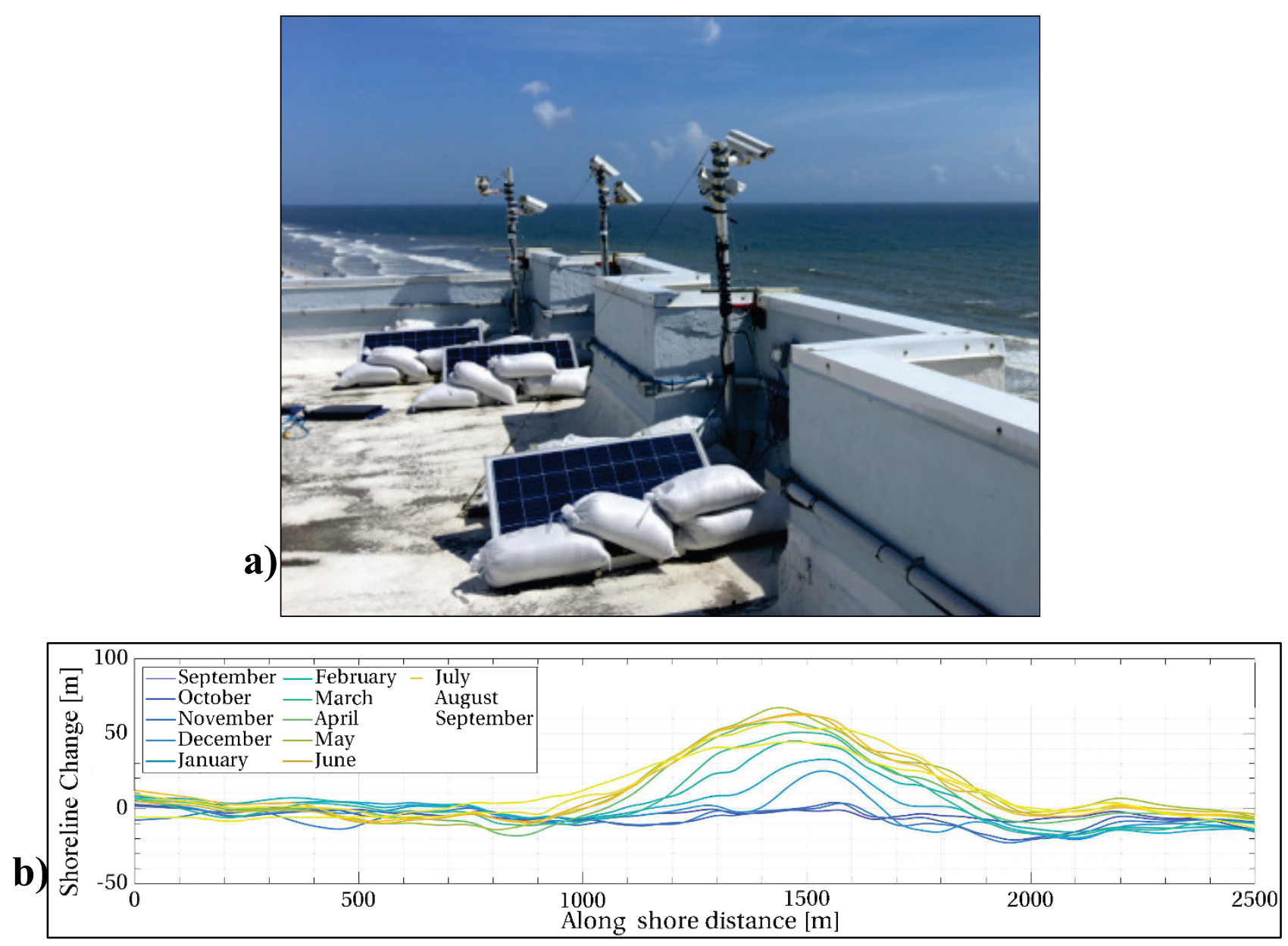

Figure 3. (a) Argus cameras installed on top of hotel and (b) shoreline change following nearshore nourishment (Onnink 2020) at New Smyrna Beach, FL. 
POST-CONSTRUCTION METRICS: The post-construction metrics are the most important for demonstrating the success of a project. These success metrics could be synthesized as

- No harm

- Placed sediment moved (or did not move)

- Shoreline or profile changed.

Each of these metrics has varying amounts of effort required to quantify them. State regulatory agencies often require evidence that no harm is done to the environment. Some examples include quantifying the endangered tiger beetle population pre-construction and post construction at Little Wicomico, VA, monitoring sea turtle nesting at numerous locations around the country and monitoring benthic habitats. Non-environmental no-harm criteria could be as simple as showing culverts near the project were not blocked by the sediment placed by the project. No injuries or loss of life of construction contractors or the public could be considered an additional success metric due to the changes in hydrodynamics resulting from nearshore placement events.

There are numerous ways to determine if the sediment placed in the nearshore moved, how the shoreline or profile changed, and no harm was created. These techniques will be broken into two categories: ancillary or regional techniques and site-specific techniques. Some ancillary or regional techniques include

- $\quad$ satellite or aerial imagery to show shoreline response

- annual topographic and bathymetric surveys

- no significant change in oyster/crab/lobster/fishing harvest subsequent year.

Site specific techniques include

- shoreline tracking and analysis

- bathymetric inversion monitoring

- sediment tracer or geo-tracer monitoring.

Each of these monitoring techniques is elaborated in the subsequent sections.

Ancillary or Regional Monitoring Techniques. Comparing imagery from satellite or airborne platforms (e.g., Google Earth, National Oceanic and Atmospheric Administration Digital Coast) are a valuable way to monitor shoreline response over time. The Seattle District used this technique to highlight the shoreline gain for a beach south of Grays Harbor, WA, and the Portland District similarly utilized it to identify beach gain at Chetco, OR. In very dynamic systems with rapid sediment transport, periodic aerial imagery can also be collected. The New Orleans District flies over its projects every year between November and December to capture the shoreline position with infrared imagery, as shown in Figure 4. These aerial images are useful because nearshore placements of 300-400,000 $\mathrm{yd}^{3}\left(230-300,000 \mathrm{~m}^{3}\right)$ can disperse within months, and the area of influence can be several miles. The annual aerial images provide a cost-effective method to monitor the shoreline response for many miles. 

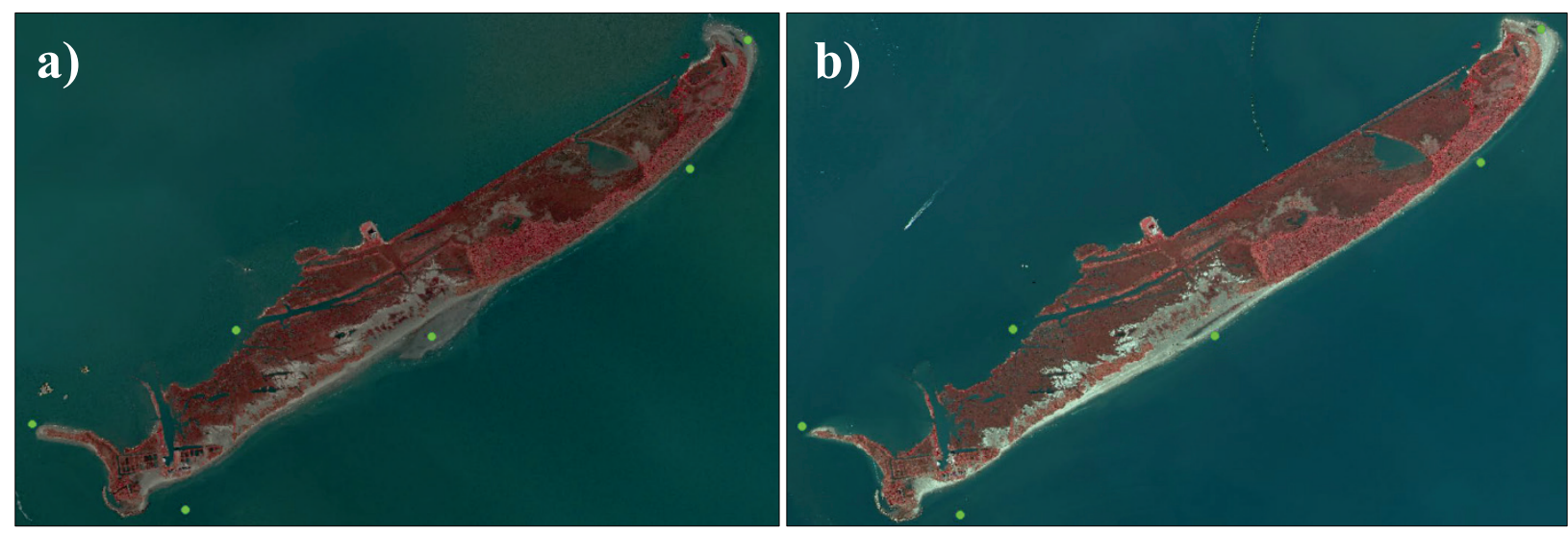

Figure 4. Annual infrared aerial imagery from Grand Terre, LA, in (a) December 2009 and (b) November 2010. The green dots are matching points. Note the shoreline gain in the center of the island in 2009 and the northern tip of the island in 2010.

Topographic and bathymetric surveys are another method to show placed sediment movement and shoreline response (Beck et al. 2012). Many projects require a post-construction survey of the project, particularly if done by a contractor. To monitor the bathymetry beyond the postconstruction survey, many locations such as South Padre Island, TX, and across the State of Florida have regular beach profile surveys. Existing survey transects that pass through nearshore nourishment project sites can provide long-term insight into the behavior of the project. Additionally, airborne lidar that is periodically collected through the Joint Airborne Lidar Bathymetry Technical Center of Expertise (Wozencraft et al. 2018) may show the long-term shoreline response. Simply showing that the sediment dispersed indicates that the sediment was captured by the littoral system and may be offsetting erosion losses that might otherwise occur to subaerial beach.

The final ancillary or regional monitoring technique is to show an oyster/crab/lobster/fishing harvest following a nearshore nourishment project that is consistent with the natural fluctuations. Seafood harvests fluctuate with or without nearshore nourishment projects. Showing a strong subsequent harvest or a harvest within the natural fluctuations is a good metric to show no harm. A long track record of this metric could be easily compiled using historical dredging and fishing records.

Site-Specific Monitoring Techniques. Shorelines may be derived from satellite and aerial imagery in addition to lidar Digital Elevation Models, which may be used to quantify the shoreline response by quantifying change rates using Geographic Information System tools such as the US Geological Survey, Digital Shoreline Analysis System (Thieler et al. 2008). This technique has been used to monitor the shoreline response for two nearshore nourishment locations on Lake Michigan, as shown in Figure 5. For the shoreline shown in Figure 5, more than 3.3M $\mathrm{yd}^{3}$ $\left(2.5 \mathrm{M} \mathrm{m}^{3}\right)$ of dredged sediment has been placed in the nearshore of Ogden Dunes from 1986 to 2016. The shoreline position was determined for each image, adjusted for the lake level, and then the shoreline change was analyzed for each set of images. The resolution of the images used for this type of analysis will directly impact the resolution of the estimated shoreline change. 
Showing a reduction in the erosion rate or progradation of the shoreline is a major success metric for most projects. To quantify the shoreline change due to the nearshore nourishment project, a control site can also be analyzed.

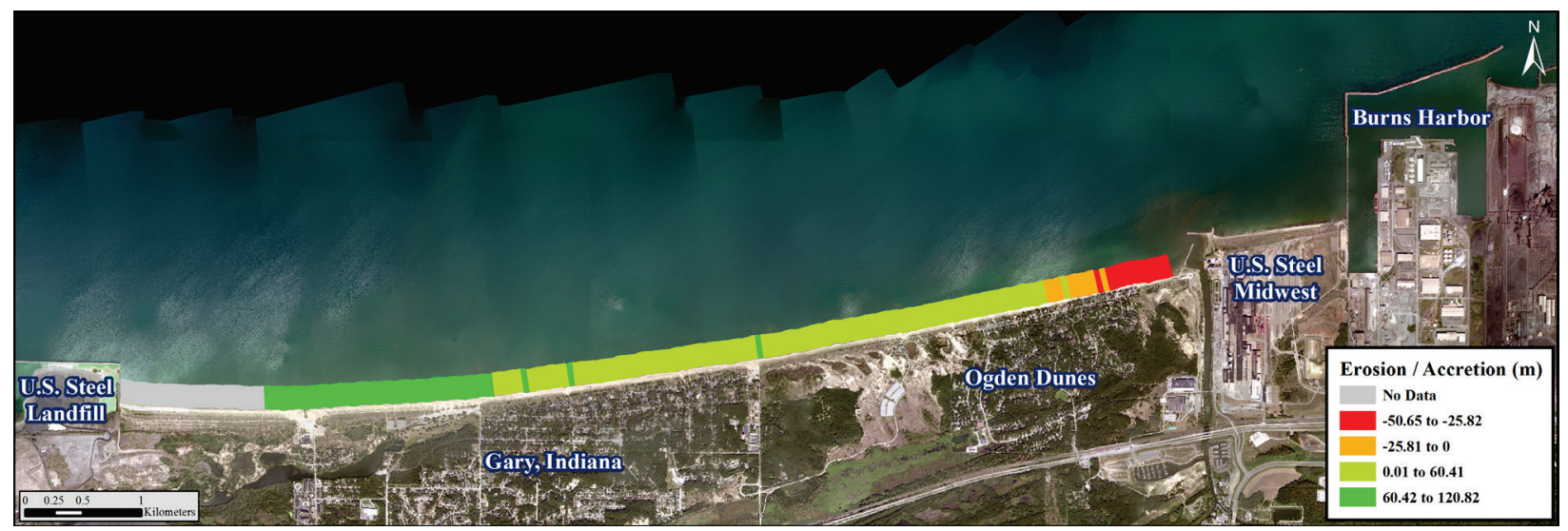

Figure 5. Shoreline accretion (green) and erosion (red) from 1969 to 2014 near the Port of Indiana (Arnold et al. 2018).

Another method to capture shoreline change and bathymetric morphologic evolution post construction is to use a type of bathymetric inversion monitoring. As discussed in the construction metrics section, the Argus (permanent) and mini-Argus (temporary) systems can estimate the hydrodynamic conditions during construction. The wave celerity measured with the Argus systems can be used to infer the bathymetry, in a process called bathymetric inversion (Holman et al. 2013). The Radar Inlet Observation System (RIOS) uses an x-band radar to measure the wave celerity and period and can use the same bathymetric inversion technique as the Argus System (McNinch et al. 2012). The RIOS system was used to monitor the nearshore nourishment at Vilano Beach, FL (Brutsché et al. 2017).

Sediment tracers or geo-tracers are another way to determine if the sediment is moving and where it is going. Sediment tracer studies have been done at nearshore nourishment projects in Brunswick, GA (Smith et al. 2007), MCR (Moritz et al. 2011), Coos Bay, OR (Li et al. 2018), and South Padre Island, TX (Figlus et al. 2021). Sediment tracer studies are expensive but are good at defining qualitative transport pathways and rates.

ADAPTIVE MANAGEMENT: The coastal nearshore is an energetic and dynamic environment. Nearshore nourishment projects successfully constructed according to the design can have alternate outcomes due to storm events or rising lake levels in the Great Lakes. To adaptively manage nearshore nourishment projects, the project success metrics, and target threshold values where feasible, should be mutually identified with stakeholders to evaluate project performance and be used for decision making to modify the project. It is also important to have a long-term strategy for the project and adaptively modify plans in such a dynamic system. Things to consider to adaptively improve the project:

- Did the sediment move at the expected rate?

- Did the nearshore nourishment positively impact the shoreline?

- Was there any feedback from the community about the project? 
Given that placement depth influences dispersal rates, if the placed sediment did not move at the expected rate, the project should consider adaptations. The rate of movement could also be affected by a slightly different sediment gradation being dredged than what was estimated from preconstruction sediment samples. If the gradation changes, the depth can still be used to control the dispersive rate of the placed sediment.

Many nearshore nourishment projects are intended to reduce shoreline erosion. Was there a reduction in the erosion? Is there another location in the alongshore where the shoreline erosion is more critical and the placement area should be moved? Local stakeholders may need to contribute funding to allow USACE to place in an area farther from the Federal Standard location.

Feedback from the public about a project could identify gaps in understanding and may involve adjusting the plan or improving the communication of the design and construction goals. Clear goals, consistent communication, and managing project expectations will position projects for success.

SUMMARY: This technical note provides practical considerations and metrics of success for nearshore nourishment projects constructed with dredged sediment. The use of success metrics will increase the beneficial use of dredged sediment through nearshore nourishment projects and garner public support in the long term. Documenting metrics of success establishes a body of evidence of successful placements without negative impacts. All 21 USACE Coastal and Great Lakes Districts were interviewed to determine what success metrics are applicable in their District. This document assembles the design considerations, construction metrics, post-construction metrics, and adaptive management considerations from these interviews.

ADDITIONAL INFORMATION: This RSM-TN was prepared as part of the USACE, Regional Sediment Management Program, Coastal Inlets Research Program, and Dredging Operations and Environmental Research program by Brian McFall, Doug Krafft, and Brooke Walker, US Army Engineer Research and Development Center, Coastal and Hydraulics Laboratory, Vicksburg, MS, and Hande McCaw, USACE New England District, Concord, MA. Questions pertaining to this RSM TN may be directed to Brian McFall (Brian.C.McFall@usace.army.mil), Doug Krafft (Douglas.R.Krafft@usace.army.mil), or to the USACE RSM Program Manager, Dr. Katherine E. Brutsché (Katherine.E.Brutsche@usace.army.mil). Additional information regarding RSM may be obtained from the RSM web site http://rsm.usace.army.mil/.

This ERDC/TN RSM-21-3 should be cited as follows:

McFall, B. C., D. R. Krafft, H. McCaw, and B. M. Walker. Metrics of Success for Nearshore Nourishment Projects Constructed with Dredged Sediment. ERDC/TN RSM-21-3. Vicksburg, MS: US Army Engineer Research and Development Center. http://dx.doi.org/10.21079/11681/41160

\section{REFERENCES}

Arnold, D. E., B. C. McFall, K. E. Brutsché, E. C. Maloney, and D. F. Bucaro. 2018. Nearshore Placement Techniques in Southern Lake Michigan. ERDC/CHL TR-18-3. Vicksburg, MS: US Army Engineer Research and Development Center. 
Bain, R. L., B. C. McFall, D. R. Krafft, and A. Hudson. 2021. "Evaluating Transport Formulations for Application to Nearshore Berms." Journal of Waterway, Port, Coastal, and Ocean Engineering.

Beck, T. M, J. D. Rosati, and J. Rosati. 2012. An Update on Nearshore Berms in the Corps of Engineers: Recent Projects and Future Needs. ERDC/CHL-CHETN-XIV-10. Vicksburg, MS: US Army Engineer Research and Development Center.

Birkemeier, W. A. 1985. "Field Data on Seaward Limit of Profile Change." Journal of Waterway, Port, Coastal and Ocean Engineering 111(3): 598-602.

Bruder, B. L., K. L. Brodie, N. J. Spore, A. D. Renaud, and K. C. Hodgens. 2019. "Continuous Monitoring of a Nearshore Berm at New Smyrna Beach, FL via Coastal Imagery." Proceedings, Coastal Sediments 2019. World Scientific 2443-2457.

Brutsché, K. E., B. C. McFall, H. Li, J. E. McNinch, J. D. Ousley, J. A. Engle, and C. K. Maglio. 2017. "Strategic Nearshore Placement of Dredged Sediment at Vilano Beach, Florida." Shore \& Beach 85(3): 77-84.

Brutsché, K. E., J. Rosati, and C. E. Pollock. 2016. Calculating Depth of Closure Using WIS Hindcast Data. ERDC/CHL CHETN-VI-45. Vicksburg, MS: US Army Engineer Research and Development Center.

Dunkin, L., E. Eismann, M. Hartman, and J. Wozencraft. 2020. Seamless Integration of Lidar-Derived Volumes and Geomorphic Features into the Sediment Budget Analysis System. ERDC/TN RSM-20-4. Vicksburg, MS: US Army Engineer Research and Development Center.

Figlus, J., Y. K. Song, C. K. Maglio, P. L. Friend, D. Schnoeblen, and K. Boburka. 2021. "Particle Tracer Analysis for Submerged Berm Placement of Dredged Material near South Padre Island, Texas." Journal of Dredging 19(1): $14-30$.

Hallermeier, R. J. 1978. "Uses for a Calculated Limit Depth to Beach Erosion.” Proceedings, Coastal Engineering $1978,1493-1512$.

Hallermeier, R. J. 1981. “A Profile Zonation for Seasonal Sand Beaches from Wave Climate.” Coastal Eng. 4: 253277.

Hands, E. B., and M. C. Allison. 1991. "Mound Migration in Deeper Water and Methods of Categorizing Active and Stable Depths." Edited by N. C. Kraus, K. J. Gingerich, and D. L. Kriebel. Proceedings, Coastal Sediments 1991, New York: American Society of Civil Engineers, 1985-1999.

Hartman, M., and A. B. Kennedy. 2016. "Depth of Closure over Large Regions Using Airborne Bathymetric Lidar." Marine Geology 379: 52-63.

Holman, R., N. Plant, and T. Holland. 2013. "cBathy: A Robust Algorithm for Estimating Nearshore Bathymetry." Journal of Geophysical Research: Oceans 118(5): 2595-2609.

Hubertz, J. M. 1992. User's Guide to the Wave Information Studies (WIS) Wave Model: Version 2.0. WIS Report 27. Vicksburg, MS: US Army Engineer Waterways Experiment Station.

Komar, P. D. 1998. Beach Processes and Sedimentation. Upper Saddle River, NJ: Prentice-Hall.

Krafft, D. R., D. L. Young, K. E. Brutsché, B. C. McFall, and B. L. Bruder. 2020. Nearshore Placement Workshop 2019: Sediment Nourishment of the Nearshore Environment. ERDC/CHL SR-20-02. Vicksburg, MS: US Army Engineer Research and Development Center.

Kraus, N. C., M. Larson, and R. Wise. 1998. Depth of Closure in Beach Fill Design. CETN II-40. Vicksburg, MS: US Army Engineer Waterways Experiment Station.

Li, H., T. M. Beck, H. R. Moritz, K. Groth, T. Puckette, J. Marsh, and A. Sanchez. 2018. "Sediment Tracer Tracking and Numerical Modeling at Coos Bay Inlet, Oregon." Journal of Coastal Research 35(1): 4-25.

McFall, B. C., and K. E. Brutsché. 2018. User's Guide for the Sediment Mobility Tool Web Application. ERDC/TN RSM-18-4. Vicksburg, MS: US Army Engineer Research and Development Center. 
McFall, B. C., K. E. Brutsché, J. D. Ousley, C. K. Maglio, and J. A. Engle. 2017. "Innovative Near-shore Berm Placement Techniques at Vilano Beach, FL and Application of the Sediment Mobility Tool." World of Dredging 51(1/2): 34-35.

McFall, B. C., K. E. Brutsché, A. M. Priestas, and D. R. Krafft. 2021. "Evaluation Techniques for the Beneficial Use of Dredged Sediment Placed in the Nearshore." Journal of Waterway, Port, Coastal and Ocean Engineering. doi: 10.1061/(ASCE)WW.1943-5460.0000648.

McFall, B. C., S. J. Smith, C. E. Pollock, J. Rosati, III, and K. E. Brutsché. 2016. Evaluating Sediment Mobility for Siting Nearshore Berms. ERDC/CHL CHETN-IV-108. Vicksburg, MS: US Army Engineer Research and Development Center.

McNinch, J. E., K. L. Brodie, and R. K. Slocum. 2012. "Radar Inlet Observing System (RIOS): Continuous Remote Sensing of Waves, Currents, and Bathymetry at Tidal Inlets." In Oceans 2012, 11-19 October 2012, Hampton Roads, VA.

Mesa, C. 1996. "Nearshore Berm Performance at Newport Beach, California, USA." Proceedings of Coastal Engineering 1996, ASCE, 4636-4349.

Moritz, H. R., T. Puckette, J. Marsh, R. Boudreau, M. Siipola, and M. Ott. 2011. "Utilizing Sediment Tracer Studies to Evaluate Transport Pathways at the Mouth of the Columbia River, USA." Proceedings of Coastal Sediments 11 .

Nadal-Caraballo, N. C., M. O. Campbell, V. M. Gonzalez, M. J. Torres, J. A. Melby, and A. A. Taflanidis. 2020. "Coastal Hazards System: A Probabilistic Coastal Hazard Analysis Framework." Journal of Coastal Research 95(sp1): 1211-1216.

Norton, J., H. R. Moritz, M. E. Ott, J. M. McMillan, and G. C. Roegner. 2018. "Advanced Monitoring of Dredged Material Placement Sites at the Mouth of the Columbia River." Proceedings of Dredging Summit and Expo '18, 266-275.

Onnink, C. J. 2020. Dynamic Shoreline Response to a Shallow Concentrated Nearshore Berm Nourishment. MS thesis. TU Delft thesis repository. Delft, The Netherlands.

Parson, L., N. Lovelace, E. Godsey, K. Reine, and J. Gailani. 2015. Regional Sediment Management (RSM) Strategy for Mobile Bay, Alabama. ERDC/CHL CHETN-XIV-41. Vicksburg, MS: US Army Engineer Research and Development Center.

Pruett, M. 2019. "Florida Pros Revel in Man-Made Sandy Slabs: How the Ponce de Leon Inlet and ICW Channel Dredging Project gave a tight crew of Floridian surfers a novelty wave to remember." Surfline. Accessed 3 Dec. 2020. www.Surfline.com,

Rosati, J. D., and N. C. Kraus. 1999. Sediment Budget Analysis System (SBAS). Coastal Engineering Technical Note IV-20. Vicksburg, MS: US Army Engineer Research and Development Center.

Smith, S. J., J. M. Marsh, and T. Puckette. 2007. "Analysis of Fluorescent Sediment Tracer for Evaluating Nearshore Placement of Dredged Material.” Proceedings XVIII World Dredging Congress 2007, 1345-1358.

Thieler, E. R., E. A. Himmelstoss, J. L. Zichichi, and E. Ayhan. 2008. Digital Shoreline Analysis System (DSAS) Version 4.0 - An ArcGIS Extension for Calculating Shoreline Change. US Geological Survey Open File Report 1278. Reston, VA: USGS.

USACE (US Army Corps of Engineers). 2019. Actual Dredge Cost Data for 1963-2018. National Data Center Annual Report. Washington, DC.

Wozencraft, J., L. Dunkin, M. Reif, and E. Eisemann. 2018. "A Spatial Index Approach to Coastal Monitoring: A Florida Case Study." Journal of Coastal Research 81: 67-75.

NOTE: The contents of this technical note are not to be used for advertising, publication, or promotional purposes. Citation of trade names does not constitute an official endorsement or approval of the use of such products. 